\title{
Long-term trends in use of and expenditures for cardiovascular medications in Canada
}

\author{
Cynthia A. Jackevicius PharmD MSc, Jafna L. Cox BA MD, Daniel Carreon BSc, Jack V. Tu MD PhD, \\ Stéphane Rinfret MD MSc, Derek So MD, Helen Johansen PhD, Dimitri Kalavrouziotis MD MSc, \\ Virginie Demers MD, Karin Humphries MBA DSc, Louise Pilote MD PhD, for the Canadian \\ Cardiovascular Outcomes Research Team
}

An abridged version of this article appeared in the July 7, 2009, issue of CMAJ.

$\infty$ See related commentary by Califf, available at www.cmaj.ca/cgi/content/full/cmaj.091101

\section{ABSTRACT}

Background: Medication expenditures have become the fastest growing sector of costs within the Canadian health care system. Evaluation of the use of cardiovascular medications is important to determine the magnitude of the growth, to identify which medications dominate the landscape and to detect interprovincial differences in utilization. We describe long-term trends in the use of and expenditures for cardiovascular medications in Canada, by drug class and by province.

Methods: For these analyses, we used volume and expenditure data related to prescriptions for cardiovascular medications obtained from IMS Health Canada's CompuScript Audit $^{\circledast}$ database for the period 1996-2006. Here, we describe national and provincial patterns of utilization and expenditures for specified classes of cardiovascular medications.

Results: The use of cardiovascular medications increased sharply in Canada during the study period, with related costs rising by over $200 \%$ during this period to surpass $\$ 5$ billion in 2006. Changes in population demographics, risk factors and inflation appeared to account for about two-thirds of the observed growth in expenditures. Use of newer medication classes (statins, angiotensin-receptor blockers, angiotensin-converting-enzyme inhibitors), for which patented brand name medications predominate, accounted for almost one-third of the cost increases. Interprovincial differences in total expenditures for cardiovascular drugs portrayed a descending gradient from east to west, with greatest variability for the newer drug classes.

Interpretation: Prescriptions and expenditures for cardiovascular medications in Canada escalated over the study period. Projected increases may reach potentially unsustainable levels. Greater emphasis on the use of cost-effective medications is required to limit further increases. Factors influencing interprovincial differences warrant further study.

Une version française de ce résumé est disponible à l'adresse www.cmaj.ca/cgi/content/full/cmaj.081913/DC1

CMAJ 2009;181(1-2):E19-E28 $\longrightarrow$ ardiovascular disease remains the leading cause of premature death and disability in Canada, representing a major societal and population burden. ${ }^{1}$ Practice guidelines have emphasized primary and especially secondary prevention of cardiovascular disease through the use of medications to reduce cardiac morbidity and mortality. ${ }^{2}$ In 2004, Canadians spent more on cardiovascular medications than on any other category of medications. ${ }^{3}$

We previously reported substantial increases in the utilization of and expenditures for cardiovascular medications in Canada between 1996 and 2001. ${ }^{4}$ We found that expenditures for cardiovascular medications more than doubled over that 6-year period and that variability in the use of specific classes of cardiac medications existed between provinces. At the time of the study, it was known that many of the medications for which utilization was increasing were associated with improved outcomes and had the potential to offset resource utilization in other sectors of the health care system, such as hospital admissions.

In the 5 years after our first report, evidence continued to accumulate supporting the use of additional classes of cardiovascular medications. ${ }^{5-16}$ Also, many cardiovascular practice guidelines were revised, and these updated guidelines could have affected the use of cardiovascular medications. ${ }^{2,17-23}$ The growing size of the elderly population and increases in life expectancy are additional drivers expanding the use of cardiovascular medications. ${ }^{24}$ Given these varied potential influences, we sought to ascertain long-term trends in the use of and spending on cardiovascular medications in Canada. Reg-

From Western University of Health Sciences (Jackevicius, Carreon), Pomona, USA; the Institute for Clinical Evaluative Sciences (Jackevicius, Tu), Toronto, Ont.; University of Toronto (Jackevicius, Tu), Toronto, Ont.; Dalhousie University (Cox, Kalavrouziotis), Halifax, NS; Sunnybrook Health Sciences Centre (Tu), Toronto, Ont.; Laval Hospital-Quebec Heart and Lung Institute and Laval University (Rinfret), Québec City, Que.; University of Ottawa Heart Institute (So), Ottawa, Ont.; Statistics Canada (Johansen), Ottawa, Ont.; McGill University Medical Centre (Demers, Pilote), Montréal, Que.; and University of British Columbia (Humphries), Vancouver, BC 
ular surveillance of such trends is important to determine whether medications that reduce morbidity and mortality appropriately dominate the landscape, to identify interprovincial differences in drug use and to inform policy-makers who need to consider the cost trends for future planning.

\section{Methods}

\section{Study design and data source}

We conducted a population-level observational cohort study using data from IMS Health Canada's CompuScript Audit ${ }^{\circledR}$ database. CompuScript is a source of prescription data obtained by measuring, through an audit, the number and estimated value of prescriptions dispensed from Canadian retail pharmacies (includes markups and professional fees). The CompuScript sample is drawn from the IMS prescription database panel, which comprises over 5000 pharmacies, representing about two-thirds of all retail pharmacies in Canada. The CompuScript panel encompasses more than 2700 stores, each stratified by province, type (chain, independent or banner) and size (large or small). Nonidentifiable electronic extracts from records of dispensed prescriptions are collected monthly from each of these pharmacies. After passing through various quality-control checks, the sample data are projected to the "universe" in each province, and provincial totals are summed to generate a national estimate. The data collected can be used to ascertain prescription volume by drug class and the market share for trending purposes, providing a measure of product utilization. Also available is the cost of the prescription as dispensed (including all markups and the pharmacist's professional fee). For this study, we used data for the period February 1996 to December 2006. The IMS Health Canada database records aggregate population-wide data rather than patient-specific data.

\section{Analysis}

We used descriptive statistics to report the data on utilization of cardiovascular medications. The specific cardiovascular medication classes of interest were oral anticoagulants, thienopyridine antiplatelet agents, nitroglycerin, $\beta$-blockers, calcium antagonists, angiotensin-converting-enzyme (ACE) inhibitors, angiotensin-receptor blockers, diuretics and statins (Appendix 1, available at www.cmaj.ca/cgi/content/full/cmaj.081913 /DC2). For each class of medications, we described trends for the number of prescriptions, the total expenditures for prescription claims (as extrapolated to the total population) and changes in expenditures over time. We used monthly utilization data to illustrate the changing trends for each medication class, at a national level, over the 11-year study period. Combination products of $\beta$-blockers, ACE inhibitors or angiotensin-receptor blockers with diuretics were included in the total numbers for each individual drug product. For interprovincial comparisons of drug use, we used expenditures as a proxy for the total number of prescriptions dispensed. We did this to minimize variability and hence misclassification errors due to differing frequency of prescription refills between provinces. We compared medication expenditures per 100000 population across provinces, using 2001 Canadian census data for population estimates, to detect any geographic variation. ${ }^{24} \mathrm{We}$ also compared changes in medication expenditures per 100000 population from 1996-2001 to 2002-2006 between provinces.

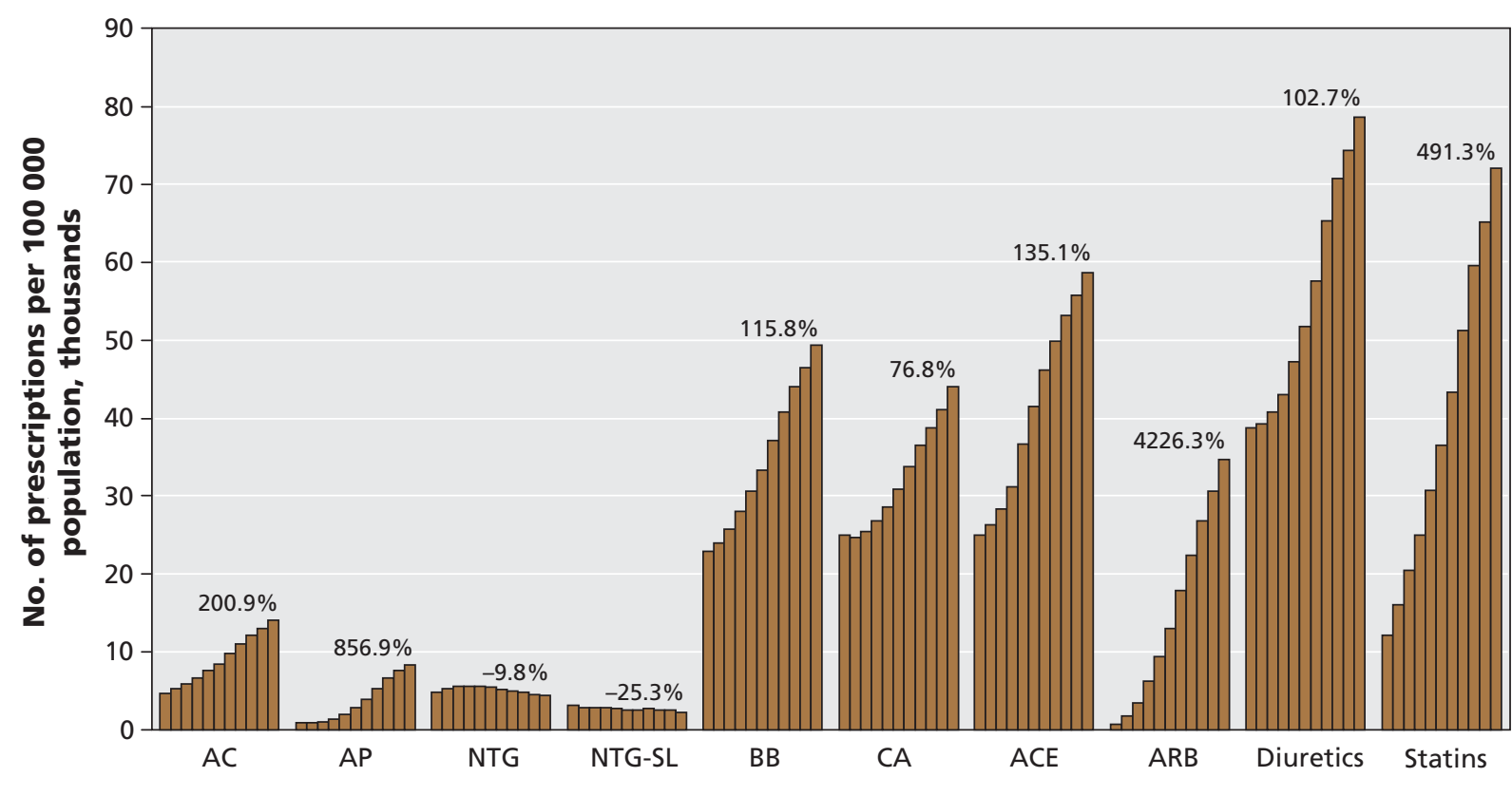

Figure 1: Annual number of drug prescriptions in Canada per 100000 population, for the period 1996-2006. Each bar represents 1 year of data between 1996 and 2006. Percent changes were calculated as 2006 data in relation to 1996 data. AC = anticoagulants, $\mathrm{ACE}=$ angiotensin-converting-enzyme inhibitors, $\mathrm{AP}=$ thienopyridine antiplatelets, $\mathrm{ARB}=$ angiotensin-receptor antagonists, $\mathrm{BB}=\beta$-blockers, $\mathrm{CA}=$ calcium antagonists, NTG = nitroglycerin, SL = sublingual. Source: IMS Health Canada, Canadian CompuScript Audit ${ }^{\oplus}$ database. 


\section{Results}

The number of prescriptions for all cardiovascular medication classes increased over the study period, with the exception of nitroglycerin products, for which utilization declined (Figure $1)$. As of 2006 , the top 3 cardiovascular medications dispensed in Canada were diuretics, statins and ACE inhibitors, whereas in 1996 the top 3 medications were diuretics, ACE inhibitors and calcium antagonists. Statin use increased rapidly over the decade. By 2006 this drug class was close to surpassing diuretics as the most commonly prescribed class of cardiovascular medications in Canada. Among all of the car- diovascular medication classes, the number of prescriptions increased most sharply for angiotensin-receptor blockers. From 1996 to 2006, the average annual change in the number of cardiovascular prescriptions ranged from an increase of $49.6 \%$ (95\% confidence interval [CI] $26.5 \%$ to $72.6 \%$ ) for angiotensin-receptor blockers to a decrease of $2.8 \%$ (95\% CI $-4.6 \%$ to $-1.1 \%$ ) for sublingual nitroglycerin. The overall average change, for all types of cardiovascular medications, was an increase of $10.3 \%$ (95\% CI $8.5 \%$ to $12.1 \%$ ) (Table 1).

Expenditures for cardiovascular medications grew at a constant rate throughout the 11-year study period, increasing by more than $200 \%$ overall (Figure 2). The mean cost per in-

Table 1: Changes in volume and expenditures for cardiovascular prescriptions, 1996-2006* (part 1)

\begin{tabular}{|c|c|c|c|c|}
\hline \multirow[b]{2}{*}{ Drug class; variable } & \multicolumn{2}{|c|}{ Year; \$† } & \multirow{2}{*}{$\begin{array}{c}\text { Relative } \\
\text { change, } \%\end{array}$} & \multirow{2}{*}{$\begin{array}{l}\text { Average annual change, } \\
1996-2006, \%(95 \% \mathrm{Cl})\end{array}$} \\
\hline & 1996 & 2006 & & \\
\hline \multicolumn{5}{|l|}{ Anticoagulants } \\
\hline No. of prescriptions & 1406010 & 4230994 & 200.92 & 11.7 (10.1 to 13.2$)$ \\
\hline Prescriptions per 100000 population & 4686 & 14100 & & \\
\hline Total cost & 35441354 & 76498554 & 115.85 & $8.2 \quad$ (3.8 to 12.6$)$ \\
\hline Cost per 100000 population & 118110 & 254935 & & \\
\hline Mean cost per prescription & 25.20 & 18.08 & -28.25 & \\
\hline \multicolumn{5}{|l|}{ Thienopyridine antiplatelet agents } \\
\hline No. of prescriptions & 261259 & 2500051 & 856.92 & 26.2 (16.6 to 35.8$)$ \\
\hline Prescriptions per 100000 population & 871 & 8332 & & \\
\hline Total cost & 23427533 & 240587242 & 926.94 & 27.2 (15.9 to 38.9$)$ \\
\hline Cost per 100000 population & 78073 & 801768 & & \\
\hline Mean cost per prescription & 89.64 & 96.23 & 7.35 & \\
\hline \multicolumn{5}{|l|}{ Nitroglycerin } \\
\hline No. of prescriptions & 1470182 & 1326829 & -9.75 & $-0.9(-3.8$ to 1.9$)$ \\
\hline Prescriptions per 100000 population & 4899 & 4422 & & \\
\hline Total cost & 56438313 & 50921905 & -9.77 & $-0.9(-3.9$ to 2.1$)$ \\
\hline Cost per 100000 population & 188083 & 169700 & & \\
\hline Mean cost per prescription & 38.39 & 38.38 & -0.03 & \\
\hline \multicolumn{5}{|l|}{ Sublingual nitroglycerin } \\
\hline No. of prescriptions & 941125 & 702684 & -25.34 & $-2.8(-4.6$ to -1.1$)$ \\
\hline Prescriptions per 100000 population & 3136 & 2342 & & \\
\hline Total cost & 15832184 & 13304567 & -15.97 & $-1.7(-3.6$ to 0.2$)$ \\
\hline Cost per 100000 population & 52761 & 44338 & & \\
\hline Mean cost per prescription & 16.82 & 18.93 & 12.54 & \\
\hline \multicolumn{5}{|l|}{$\beta$-Blockers } \\
\hline No. of prescriptions & 6860893 & 14803817 & 115.77 & $8.0 \quad(6.8$ to 9.3$)$ \\
\hline Prescriptions per 100000 population & 22864 & 49334 & & \\
\hline Total cost & 193165515 & 342515800 & 77.32 & 5.9 (3.9 to 8.0$)$ \\
\hline Cost per 100000 population & 643733 & 1141449 & & \\
\hline Mean cost per prescription & 28.15 & 23.14 & -17.80 & \\
\hline \multicolumn{5}{|l|}{ Calcium antagonists } \\
\hline No. of prescriptions & 7490159 & 13243599 & 76.81 & 5.9 (4.1 to 7.7$)$ \\
\hline Prescriptions per 100000 population & 24961 & 44135 & & \\
\hline Total cost & 510550730 & 869823073 & 70.37 & 5.6 (2.7 to 8.4$)$ \\
\hline
\end{tabular}


Table 1: Changes in volume and expenditures for cardiovascular prescriptions, 1996-2006* (part 2)

\begin{tabular}{|c|c|c|c|c|c|}
\hline \multirow[b]{2}{*}{ Drug class; variable } & \multicolumn{2}{|c|}{ Year; \$† } & \multirow{2}{*}{$\begin{array}{c}\text { Relative } \\
\text { change, \% }\end{array}$} & \multirow{2}{*}{\multicolumn{2}{|c|}{$\begin{array}{l}\text { Average annual change, } \\
1996-2006, \%(95 \% \mathrm{Cl})\end{array}$}} \\
\hline & 1996 & 2006 & & & \\
\hline Cost per 100000 population & 1701433 & 2898725 & & & \\
\hline Mean cost per prescription & 68.16 & 65.68 & -3.64 & & \\
\hline \multicolumn{6}{|c|}{ Angiotensin-converting-enzyme inhibitors } \\
\hline No. of prescriptions & 7488248 & 17605685 & 135.11 & 9.0 & (6.5 to 11.5$)$ \\
\hline Prescriptions per 100000 population & 24955 & 58672 & & & \\
\hline Total cost & 404926478 & 956662583 & 136.26 & 9.1 & (6.1 to 12.1$)$ \\
\hline Cost per 100000 population & 1349436 & 3188121 & & & \\
\hline Mean cost per prescription & 54.07 & 54.34 & 0.50 & & \\
\hline \multicolumn{6}{|l|}{ Angiotensin-receptor blockers } \\
\hline No. of prescriptions & 241096 & 10430651 & 4226.35 & 49.6 & (26.5 to 72.6$)$ \\
\hline Prescriptions per 100000 population & 803 & 34761 & & & \\
\hline Total cost & 13586755 & 608561142 & 4379.08 & 50.5 & (25.7 to 75.3$)$ \\
\hline Cost per 100000 population & 45278 & 2028058 & & & \\
\hline Mean cost per prescription & 56.39 & 58.34 & 3.46 & & \\
\hline \multicolumn{6}{|l|}{ Diuretics } \\
\hline No. of prescriptions & 11648537 & 23615881 & 102.74 & 7.4 & (5.1 to 9.7 ) \\
\hline Prescriptions per 100000 population & 38819 & 78701 & & & \\
\hline Total cost & 133479671 & 245623245 & 84.02 & 6.4 & (3.0 to 9.8 ) \\
\hline Cost per 100000 population & 444827 & 818551 & & & \\
\hline Mean cost per prescription & 11.46 & 10.40 & -9.25 & & \\
\hline \multicolumn{6}{|l|}{ Statins } \\
\hline No. of prescriptions & 3657102 & 21625086 & 491.32 & 19.6 & (15.4 to 23.9$)$ \\
\hline Prescriptions per 100000 population & 12187 & 72067 & & & \\
\hline Total cost & 348469169 & 1856909652 & 432.88 & 18.5 & (13.2 to 23.8$)$ \\
\hline Cost per 100000 population & 1161289 & 6188236 & & & \\
\hline Mean cost per prescription & 95.29 & 85.87 & -9.89 & & \\
\hline \multicolumn{6}{|l|}{ Total } \\
\hline No. of prescriptions & 41464611 & 110085277 & 165.49 & 10.3 & (8.5 to 12.1$)$ \\
\hline Prescriptions per 100000 population & 138183 & 366864 & & & \\
\hline Total cost & 1735317702 & 5261407762 & 203.20 & 11.8 & (9.3 to 14.3 ) \\
\hline Cost per 100000 population & 5783025 & 17533880 & & & \\
\hline Mean cost per prescription & 41.85 & 47.79 & 14.20 & & \\
\hline
\end{tabular}

Note: $\mathrm{Cl}=$ confidence interval.

*Data source: IMS Health Canada, Canadian CompuScript Audit ${ }^{\oplus}$

tUnless indicated otherwise.

dividual cardiovascular prescription increased by $14.2 \%$, from $\$ 41.85$ in 1996 to $\$ 47.79$ in 2006 per prescription dispensed (Table 1). In 2006, total costs of cardiovascular medications exceeded $\$ 5$ billion, with statins accounting for nearly $40 \%$ of this spending. As of 2006, the cardiovascular medication classes associated with the highest expenditures were statins, ACE inhibitors and calcium antagonists, in that order. The same drugs accounted for the highest expenditures in 1996, but the order was calcium antagonists, ACE inhibitors and statins (Figure 3). In 2006, calcium antagonists were the fifth highest medication class by utilization, but they represented the third highest medication class for expenditures. Nationwide, angiotensin-receptor blockers were associated with the highest annual rate of increase in expenditures and, given current trends, may soon surpass calcium antagonists and ACE inhibitors in their proportionate contribution to overall expenditures.

The number of prescriptions for antihypertensive drug classes ( $\beta$-blockers, calcium antagonists, ACE inhibitors, angiotensin-receptor blockers and diuretics) rose by $136 \%$ 


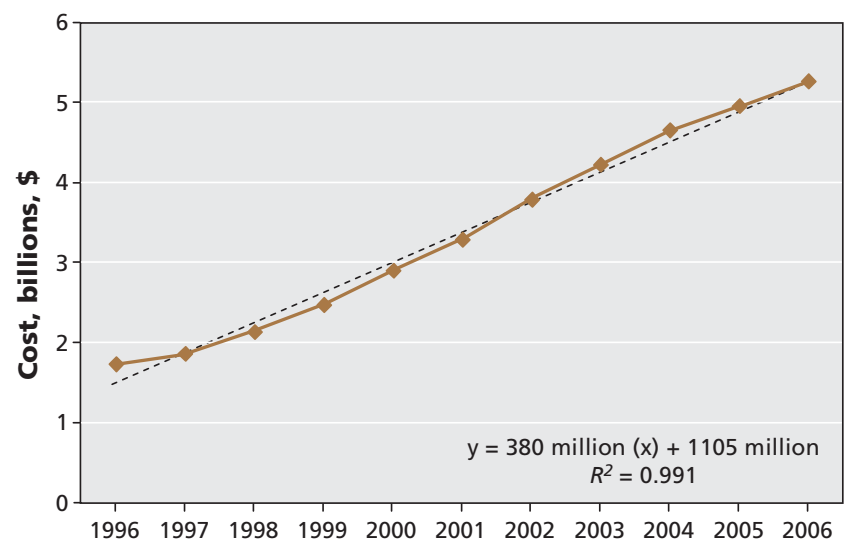

Figure 2: Costs for cardiovascular medications by year, from 1996 to 2006. Source: IMS Health Canada, Canadian CompuScript Audit ${ }^{\oplus}$ database.

from 1996 to 2005, and associated expenditures rose by $141 \%$ during the same period. Even after adjustment for the $91 \%$ increase in the number of Canadians with hypertension during the study period, the annual cost of antihypertensive prescriptions per individual with hypertension increased by $19.4 \% .^{25,26}$ Contributors to this increase may also include the $15.6 \%$ increase in the annual number of antihypertensive prescriptions dispensed per individual with hypertension (12.21 per year in 1996 and 14.12 per year in 2005) and the 3.3\% increase in the mean cost of individual antihypertensive prescriptions (\$37.23 per prescription in 1996 and $\$ 38.46$ per prescription in 2005).

\section{Variations in total expenditures by province}

Between 1996 and 2006, the total expenditures for cardiovascular medications dispensed per 100000 population varied by province. In 2006, total expenditures were lowest in the western provinces and highest in Quebec, New Brunswick and Nova Scotia (Figure 4). We also observed variation in provincial expenditures when we analyzed the data by individual medication class (see Appendix 2, available at www.cmaj.ca /cgi/content/full/cmaj.081913/DC2). In 2006, expenditures were highest for statins and second-highest for ACE inhibitors in all provinces except Quebec, where calcium antagonists represented the second-highest expenditure. Quebec had the highest per capita expenditures for 4 of the 9 cardiovascular medication classes examined (statins, angiotensin-receptor blockers, diuretics and sublingual nitroglycerin), whereas New Brunswick had the highest per capita expenditures for ACE inhibitors, nitroglycerin and calcium antagonists. For all but 3 cardiovascular medication classes, the lowest per capita expenditure occurred in 1 of the 3 westernmost provinces (British Columbia, Alberta or Saskatchewan). The exceptions were angiotensin-receptor blockers and anticoagulants, for which the provinces of Newfoundland and Labrador, and Prince Edward Island (combined) had the lowest expenditures, and ACE inhibitors, for which Quebec had the lowest expenditures.

There was moderate variation in the rank order of per capita expenditures by medication class within each province in 2006. However, expenditures for those prescriptions varied by more than 2 -fold for 4 of the 9 cardiovascular medication classes evaluated.

In 2006, the ratio of highest to lowest provincial per capita

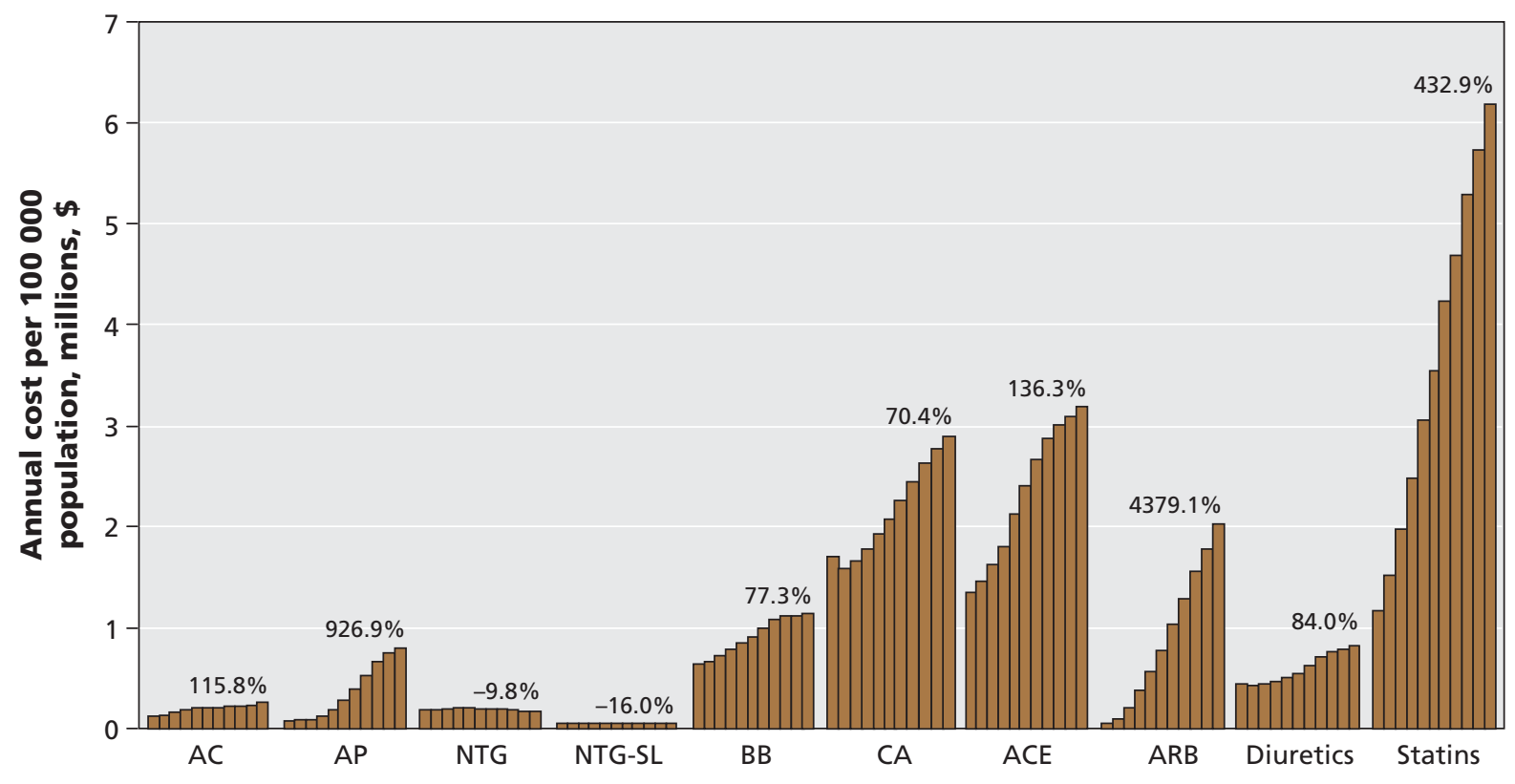

Figure 3: Annual cost for cardiovascular medications in Canada per 100000 population, for the period 1996-2006. Each bar represents 1 year of data between 1996 and 2006. Percent changes were calculated as 2006 data in relation to 1996 data. AC = anticoagulants, $A C E=$ angiotensin-converting-enzyme inhibitors, $A P=$ thienopyridine antiplatelets, $A R B=$ angiotensin-receptor antagonists, BB = $\beta$-blockers, CA = calcium antagonists, NTG = nitroglycerin, SL = sublingual. Source: IMS Health Canada, Canadian CompuScript Audit $^{\circledR}$ database. 
expenditures was 2 or more for nitroglycerin (2.6), angiotensinreceptor blockers (2.1), statins (2.1) and $\beta$-blockers (2.0) (see Appendix 2), which represents high interprovincial variability in expenditures for these cardiovascular medications.

\section{Temporal changes in expenditures by province}

When we compared the first half of the study period (1996-2001) with the second half (2002-2006), we found distinct patterns regarding changes in per capita expenditures for cardiovascular medications by province (Table 2). By far the greatest increases in expenditures were for angiotensinreceptor blockers and thienopyridines, with increases for angiotensin-receptor blockers exceeding 300\% in all provinces. This pair of drug classes was followed by statins, for which expenditures increased by more than $120 \%$ in all provinces. For most provinces, increases were small to moderate, between $1 \%$ and 99\%, for ACE inhibitors, diuretics, calcium antagonists, $\beta$-blockers and anticoagulants. In most provinces, there was a decline in expenditures associated with nitroglycerin prescriptions dispensed over the study period. Increases in expenditures for most medication classes were greater in the western Canadian provinces than the eastern provinces. Manitoba had the highest or second highest increases in per capita spending for 6 of the 10 medication classes evaluated.

\section{Interpretation}

In this population-based study, we observed a sharp and steady increase in the use of and expenditures for cardiovascular medications in Canada, with expenditures increasing more than $200 \%$ over the decade of study. Cardiovascular medications are the most commonly prescribed drugs in
Canada, representing 1 of every 5 prescriptions. ${ }^{27}$ Expenditures for these drugs are far outpacing overall increases in drug costs and international growth rates for expenditures on cardiovascular drugs from the decade preceding our study. ${ }^{28}$ A recent Canadian report ${ }^{3}$ found that between 1994 and 2004, expenditures on all prescription drugs increased by $97 \%$, meaning that the rate of increase in costs for cardiovascular medications was more than twice that estimated for all medication expenditures in Canada. ${ }^{3,27,29}$ A report of cardiovascular drug use in 12 countries of the Organisation for Economic Co-operation and Development ${ }^{28}$ cited average annualized growth in expenditures of $6.2 \%$ between 1989 and 1999 .

We observed no plateau in spending on cardiovascular medications in Canada during the study period. If expenditures continue to increase at these rates, annual costs for cardiovascular medications alone will reach about $\$ 10.6$ billion in Canada by 2020. In 2007, Canadians spent 17 cents of every health care dollar on medication costs, which represented a $16 \%$ increase in proportional health care spending since $1997 .{ }^{29}$ This rapid escalation in costs for cardiovascular drugs threatens the sustainability of public drug insurance programs. Increases of this magnitude over such a relatively short period deserve further scrutiny.

Increases in the use of cardiovascular medications over time may be explained by changes in demographic characteristics and risk factor profiles of the Canadian population and changes in the economy, as summarized in Table 3. From 1996 to 2006, pharmaceutical-specific inflation in Canada increased by about $11 \%$, which might have contributed to the increased expenditures. ${ }^{30}$ The Canadian Institute for Health Information has reported that, although total population growth in Canada is about $1.1 \%$ annually, the growth has been gradual and was unlikely to account for increases in

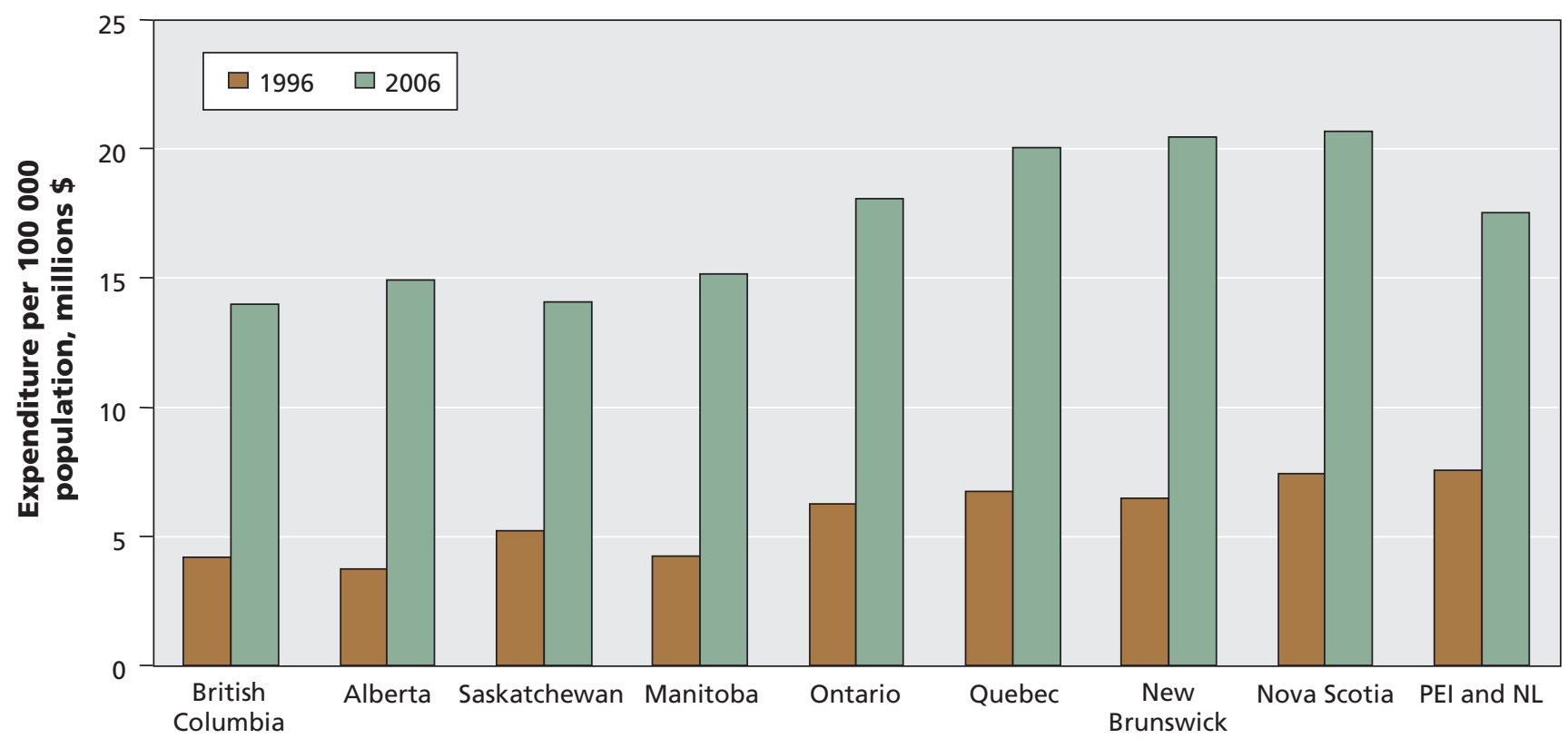

Figure 4: Expenditures for cardiovascular drugs per 100000 population by province, 1996 and 2006. Source: IMS Health Canada, Canadian CompuScript Audit ${ }^{\circledR}$ database. 
overall drug expenditures. ${ }^{29}$ Cardiovascular disease is more prevalent with age, and older people are therefore more likely to require cardiovascular medications. During our study period, the proportion of the Canadian population older than 65 years increased by about $9 \% .{ }^{24}$ Self-reported surveys of risk factors in the Canadian population over time have revealed that prevalence rates of diabetes and hypertension increased dramatically over the decade of our study, whereas rates of obesity increased moderately and smoking rates declined. ${ }^{31}$ Escalating rates of hypertension may explain increased use of antihypertensive medications in Canada, but not increased use of other medication classes. Overall, these demographic, population and economic factors potentially explain $136 \%$ or two-thirds of the increase in cardiovascular medication expenditures that we observed.

The mean cost of an individual cardiovascular prescription increased by $14.2 \%$ between 1996 and 2006, but overall growth in expenditures for cardiovascular medications exceeded $200 \%$. Given that the prices of individual drugs have been relatively stable over the last decade, increases in drug costs are more likely due to increased prescription volume, as determined by the potentially influential factors previously described, and to an increase in the use of newer, more expensive medications. ${ }^{29,32} \mathrm{We}$ observed that the use of newer medication classes, such as angiotensin-receptor blockers and statins, increased at a faster rate than the use of older medication classes, such as diuretics and $\beta$-blockers. The use of patented (or brand name) medications as a proportion of sales of all prescription drugs in Canada increased by $58 \%$ in the study period, from $45 \%$ in 1996 to $71 \%$ in $2006 .^{33}$ This transition to greater use of patented medications, which tend to be more expensive than nonpatented (generic) medications, po- tentially explains about $60 \%$ of the increased expenditures that we observed. ${ }^{29,33}$ Scrutiny of this shift is warranted, particularly where a class effect has been demonstrated, since older, more established and hence less expensive medications may be the most cost-effective option. ${ }^{34,35}$

Between 1996 and 2006, an average of 88 new patented drugs were made available annually in Canada, with only $20 \%-25 \%$ of these representing new active substances. ${ }^{33}$ This means that many of the new brand name medications may not represent major therapeutic advances. Morgan and colleagues ${ }^{36}$ recently studied overall drug expenditures in one Canadian province, British Columbia, and found that $80 \%$ of the increases in drug costs were due to use of new patented medications that were not considered to offer an important therapeutic advantage.

The costs of generic drugs may also be contributing to rising cardiovascular drug costs. The median price of generic drugs is higher in Canada than in 11 other developed countries. ${ }^{37}$ The National Pharmaceutical Strategy noted that if Canada had not exceeded the international median price for generic drugs in 2005 , the country could have saved $\$ 1.5$ billion in medication costs during that year. Given that cardiovascular medications account for about $20 \%-25 \%$ of all drug costs, a saving of about $\$ 350$ million per year could have accrued from more controlled pricing within this group of drugs alone..$^{38}$

We found that the medication classes with the greatest increases in number of prescriptions dispensed and associated expenditures were angiotensin-receptor blockers, antiplatelet agents, statins and ACE inhibitors. Many of the medications in these classes are brand name drugs, particularly for angiotensin-receptor blockers, which had the largest percentage increases in use and costs. Numerous clinical trials and guide-

Table 2: Changes in expenditures for cardiovascular drugs per 100000 population between 1996-2001 and 2002-2006

\begin{tabular}{|c|c|c|c|c|c|c|c|c|c|}
\hline \multirow[b]{2}{*}{ Drug class } & \multicolumn{9}{|c|}{ Province; $\%$ change } \\
\hline & $\mathrm{BC}$ & $A B$ & SK & $\mathrm{MB}$ & ON & $\mathrm{QC}$ & NB & NS & NL/PEI \\
\hline Nitroglycerin & -5 & -17 & 7 & 38 & 21 & -30 & -15 & -13 & -23 \\
\hline Sublingual nitroglycerin & -10 & -1 & -16 & 13 & -9 & -7 & -13 & -14 & -9 \\
\hline Anticoagulants & 28 & 31 & 10 & 46 & 38 & 49 & 20 & 24 & 14 \\
\hline$\beta$-Blockers & 57 & 59 & 49 & 82 & 41 & 39 & 40 & 23 & 21 \\
\hline Calcium antagonists & 51 & 74 & 44 & 83 & 41 & 43 & 46 & 33 & 31 \\
\hline Diuretics & 111 & 64 & 27 & 102 & 60 & 46 & 51 & 37 & 24 \\
\hline ACE inhibitors & 82 & 71 & 52 & 75 & 64 & 56 & 88 & 64 & 55 \\
\hline Statins & 128 & 168 & 130 & 156 & 121 & 124 & 153 & 140 & 166 \\
\hline Thienopyridine antiplatelet agents & 289 & 399 & 315 & 311 & 345 & 431 & 347 & 227 & 201 \\
\hline Angiotensin-receptor blockers & 398 & 348 & 319 & 341 & 347 & 331 & 502 & 309 & 401 \\
\hline
\end{tabular}

Note: $\mathrm{ACE}=$ angiotensin-converting-enzyme

*Data source: IMS Health Canada, Canadian CompuScript Audit ${ }^{\circledast}$.

\begin{tabular}{|l|l|l|l|l|l|}
\hline$\geq 400 \%$ & $100 \%$ to $399 \%$ & $50 \%$ to $99 \%$ & $1 \%$ to $49 \%$ & $-9 \%$ to $0 \%$ & $-10 \%$ or greater \\
\hline
\end{tabular}


lines have been published in recent years that provide evidence supporting the expanded use of these drug classes. ${ }^{2,5-23}$ However, whether these drugs should be replacing older, established medications is debatable. ${ }^{34,35}$ The recommendations in hypertension guidelines, which have traditionally favoured relatively cheaper diuretics and $\beta$-blockers as first-line therapies, have been revised over the years to include more expensive ACE inhibitors, angiotensin-receptor blockers and calcium antagonists as possible first-line agents. There is also an increasing trend for recommending combination therapy if there is only a partial response to monotherapy, whereas previous recommendations suggested dose escalation or switching to an alternative monotherapy if the initial treatment was only partially effective. ${ }^{19,20}$ These guideline changes, along with the increasing prevalence of hypertension in Canada, may have influenced the increased use of antihypertensive medications, particularly newer, more expensive agents, such as ACE inhibitors and angiotensin-receptor blockers. ${ }^{39}$

Total per capita spending on cardiovascular prescriptions differed across the provinces by about $50 \%$, representing variability in expenditures for cardiovascular medications across Canada. Variability was especially high for the newer medication classes, such as angiotensin-receptor blockers and statins. We found a descending east-to-west gradient in the use of and attendant cost for cardiovascular medications, with higher rates of both use and expenditures in eastern Canada. The prevalence of cardiac risk factors and overt cardiovascular disease has been found to have a east-to-west gradient, with higher rates in the east. ${ }^{40}$ Potentially, then, some of the increased use may appropriately reflect greater clinical need.

Table 3: Factors potentially influencing cardiovascular drug prescribing in Canada*

\begin{tabular}{lrrr}
\hline & \multicolumn{2}{c}{$\begin{array}{c}\text { Year; \% of } \\
\text { populationt }\end{array}$} & $\begin{array}{c}\text { Relative } \\
\text { change, \% }\end{array}$ \\
\cline { 2 - 3 } Factor & 1994 & 2005 & 77 \\
\hline Cardiac risk factors & & & \\
Hypertension & 8.2 & 14.6 & 45 \\
\hline Diabetes mellitus & 2.5 & 3.6 & -25 \\
\hline Current smoking & 24.4 & 18.2 & 18 \\
\hline $\begin{array}{l}\text { Obesity } \\
\text { Subtotal }\end{array}$ & 9.5 & 11.2 & 115 \\
\hline $\begin{array}{l}\text { Other factors } \\
\text { Inflation rate for } \\
\text { prescription medications } \\
\text { (Consumer Price Index), \% }\end{array}$ & 1996 & 2006 & \\
\hline $\begin{array}{l}\text { C65 yr } \\
\text { Patented drugs sales, } \\
\text { relative to all prescription } \\
\text { sales in Canada, \% }\end{array}$ & 12.1 & 101.2 & 9 \\
\hline $\begin{array}{l}\text { Subtotal } \\
\text { Total }\end{array}$ & 45.0 & 71.0 & 58 \\
\hline
\end{tabular}

*Data sources: CANSIM, ${ }^{31}$ Statistics Canada, ${ }^{24-26}$ Canadian Institute for Health Information, ${ }^{27}$ Patented Medicine Prices Review Board. ${ }^{37}$

tUnless indicated otherwise.
Quebec, New Brunswick and Nova Scotia had higher per capita expenditures for cardiovascular drugs than the other provinces. Our observation of Quebec's higher expenditures for cardiovascular medications is consistent with a 2007 report on drug expenditures from the Canadian Institute for Health Information, which showed that Quebec had the highest total drug costs as a proportion of total health expenditures among all Canadian provinces. ${ }^{27}$

In contrast to the descending east-to-west gradient for cumulative total cardiovascular drug expenditures from 1996 to 2006, we found a predominantly inverse west-to-east gradient for relative increases in use and expenditures for cardiovascular medications between 1996-2001 and 2002-2006; these increases were greatest for western Canada. Thus, although the western provinces initially seemed more frugal than the eastern provinces in their use of and expenditures for cardiovascular medications, they experienced a "catchup" during the second half of the study period. One factor driving higher rates of prescriptions and costs in the west may be the proliferation of the Internet pharmacy business in Manitoba, which experienced among the highest recent increases of any province. Despite this extraneous factor influencing cardiovascular drug expenditures, other western provinces, most notably British Columbia, had some of the highest rates of increase for several classes of cardiovascular medications, even though they had the lowest expenditures in the earlier period. Further exploration of interprovincial variability in rates of increase for cardiovascular drug expenditures is warranted to identify underlying causes for the observed regional differences. Potential factors include differences in demographic characteristics, risk factors, drug policies or responses to national pharmaceutical initiatives, such as participation in the Common Drug Review.

\section{Limitations}

Our study had some limitations. IMS Health Canada uses data collected from audits of prescriptions dispensed to describe general trends in drug utilization. As such, these data do not reflect exact drug utilization by individual patients or providers to determine the appropriateness of drug use. We did not have access to clinical data, such as medical conditions, blood pressure or cholesterol levels, to determine whether the prescribing of these medications was clinically appropriate. Although we observed increased use of cardiovascular medications, we could not evaluate the effects on patient outcomes and cost-effectiveness. Despite these limitations, these data provided a nationally representative sample of prescriptions, allowing us to highlight important national and provincial trends in the use of cardiovascular medications and associated spending.

\section{Conclusion}

Prescriptions and expenditures for cardiovascular medications escalated over the period 1996 to 2006 in Canada. Projected increases may reach potentially unsustainable levels. Although many demographic, economic and population factors may have contributed to these increases, newer classes of cardiovascular medications represented a large driver of escalat- 
ing use and costs, contributing to substantial interprovincial variability in medication use. Given the magnitude of growth of the expenditures involved, ensuring the prescribing of costeffective medications is essential.

Additional graphs and PowerPoint slides of data from this study are available for presentations at www.ccort.ca/Trends.aspx.

This article has been peer reviewed.

Competing interests: Stéphane Rinfret has received research grants and consulting honoraria from Pfizer Canada, BMS and Sanofi-Aventis. Jafna Cox has received honoraria or consulting fees from Bristol-Myers Squibb, Merck, Pfizer and Sanofi-Aventis and has received research funding support from Merck and Pfizer. No competing interests declared by the other authors.

Contributors: All of the authors contributed to the conception and design of the study, the acquisition and interpretation of the data, and the drafting and revising of the manuscript. All of the authors approved the final version submitted for publication.

Acknowledgements: We gratefully acknowledge IMS Health Canada, in particular the Public Affairs and Government Relations Department, for generously providing, from the CompuScript Audit ${ }^{\oplus}$, the data required for the analyses presented here. We also acknowledge Seta San, for assistance with manuscript preparation.

Funding: This study was supported by a Team Grant in Cardiovascular Outcomes Research to the Canadian Cardiovascular Outcomes Research Team from the Canadian Institutes of Health Research (CIHR). Dr. Tu is supported by a Canada Research Chair in Health Services Research, Ottawa, Ontario, and by a Career Investigator award from the Heart and Stroke Foundation of Ontario, Toronto, Ontario. The Institute for Clinical Evaluative Sciences is supported by an operating grant from the Ontario Ministry of Health and Long-Term Care, Toronto, Ontario. Virginie Demers is supported by a Canadian Cardiovascular Outcomes Research Team student grant funded through a CIHR Research Team Grant in Cardiovascular Outcomes Research. Dr. Rinfret is a junior physician scientist supported by the Fonds de la Recherche en Santé du Québec. Dr. Kalavrouziotis is supported by a Canadian Cardiovascular Outcomes Research Team Masters student fellowship. Dr. Pilote is a James McGill Chair and investigator supported by the Fonds de la Recherche en Santé du Québec. The results and conclusions are those of the authors, and should not be attributed to any of the funding or sponsoring agencies. All decisions regarding the study design, publication and data analysis were made independent of the funding agencies.

\section{REFERENCES}

1. The growing burden of heart disease and stroke in Canada 2003. Ottawa (ON): Heart and Stroke Foundation of Canada; 2003.

2. Smith SC Jr, Allen J, Blair SN, et al. AHA/ACC guidelines for secondary prevention for patients with coronary and other atherosclerotic vascular disease: 2006 update endorsed by the National Heart, Lung, and Blood Institute. J Am Coll Cardiol 2006;47:2130-9.

3. Morgan S, McMahon M, Lam J, et al. The Canadian Rx atlas. 1st ed. Vancouver (BC): University of British Columbia, Centre for Health Services and Policy Research; 2005. Available: www.chspr.ubc.ca/rxatlas/canada (accessed 2008 June 24)

4. Jackevicius CA, Tu K, Filate W, et al.; Canadian Cardiovascular Outcomes Research Team. Trends in cardiovascular drug utilization and drug expenditures in Canada between 1996 and 2001. Can J Cardiol 2003;19:1359-66.

5. Yusuf S, Sleight P, Pogue J, et al. Effects of an angiotensin-converting enzyme inhibitor, ramipril, on cardiovascular events in high-risk patients. The Heart Outcomes Prevention Evaluation Study Investigators. N Engl J Med 2000;342:145-53.

6. Dahlöf B, Sever PS, Poulter NR, et al.; ASCOT Investigators. Prevention of cardiovascular events with an antihypertensive regimen of amlodipine adding perindopril as required versus atenolol adding bendroflumethiazide as required, in the Anglo-Scandinavian Cardiac Outcomes Trial - Blood Pressure Lowering Arm (ASCOT-BPLA): a multicentre randomised controlled trial. Lancet 2005;366: 895-906.

7. Fox KM; EURopean trial On reduction of cardiac events with Perindopril in stable coronary Artery disease Investigators. Efficacy of perindopril in reduction of cardiovascular events among patients with stable coronary artery disease: randomised, double-blind, placebo-controlled, multicentre trial (the EUROPA study). Lancet 2003;362:782-8.

8. Cohn JN, Tognoni G; Valsartin Heart Failure Trial Investigators. A randomized trial of the angiotensin-receptor blocker valsartan in chronic heart failure. $N$ Engl J Med 2001;345:1667-75.

9. Pfeffer MA, Swedberg K, Granger CB, et al.; CHARM Investigators and Committees. Effects of candesartan on mortality and morbidity in patients with chronic heart failure: the CHARM-Overall programme. Lancet 2003;362:759-66.

10. Dickstein K, Kjekshus J. Effects of losartan and captopril on mortality and morbidity in high-risk patients after acute myocardial infarction: the OPTIMAAL randomised trial. Lancet 2002;360:752-60.

11. Dahlöf B, Devereux RB, Kjeldsen SE, et al.; LIFE study group. Cardiovascular morbidity and mortality in the Losartan Intervention For Endpoint reduction in hypertension study (LIFE): a randomised trial against atenolol. Lancet 2002;359:995-1003.

12. Heart Protection Study Collaborative Group. MRC/BHF Heart Protection Study of cholesterol lowering with simvastatin in 20,536 high-risk individuals: a randomised placebo-controlled trial. Lancet 2002;360:7-22.

13. Schwartz GG, Olsson AG, Ezekowitz MD, et al.; Myocardial Ischemia Reduction with Aggressive Cholesterol Lowering (MIRACL) Study Investigators. Effects of atorvastatin on early recurrent ischemic events in acute coronary syndromes: the MIRACL study: a randomized controlled trial. JAMA 2001;285:1711-8.

14. Cannon CP, Braunwald E, McCabe CH, et al.; Pravastatin or Atrovastatin Evaluation and Infection Therapy - Thrombolysis in Myocardial Infarction 22 Investigators. Intensive versus moderate lipid lowering with statins after acute coronary syndromes. N Engl J Med 2004;350:1495-504.

15. Sever PS, Dahlöf B, Poulter NR, et al.; ASCOT Investigators. Prevention of coronary and stroke events with atorvastatin in hypertensive patients who have average or lower-than-average cholesterol concentrations, in the Anglo-Scandinavian Cardiac Outcomes Trial - Lipid Lowering Arm (ASCOT-LLA): a multicentre randomised controlled trial. Lancet 2003;361:1149-58.

16. LaRosa JC, Grundy SM, Waters DD, et al.; Treating to New Targets (TNT) Investigators. Intensive Lipid Lowering with Atorvastatin in Patients with Stable Coronary Disease. N Engl J Med 2005;352:1425-35.

17. Hunt SA, Abraham WT, Chin MH, et al. ACC/AHA 2005 guideline update for the diagnosis and management of chronic heart failure in the adult: a report of the American College of Cardiology/American Heart Association Task Force on Practice Guidelines (Writing Committee to Update the 2001 Guidelines for the Evaluation and Management of Heart Failure). Circulation 2005;112:e154-e235. Available: http://circ.ahajournals.org/cgi/content/full/112/12/e154 (accessed 2009 Apr. 15).

18. Arnold JMO, Liu P, Demers C, et al. Canadian Cardiovascular Society consensus conference recommendations on heart failure 2006: diagnosis and management [published erratum in Can J Cardiol 2006;22:271]. Can J Cardiol 2006;22:23-45.

19. Khan NA, McAlister FA, Lewanczuk RZ, et al.; Canadian Hypertension Education Program. The 2005 Canadian Hypertension Education Program recommendations for the management of hypertension: part II - therapy. Can J Cardiol 2005;21:657-72.

20. Chobanian AV, Bakris GL, Black HR, et al.; National Heart, Lung, and Blood Institute Joint National Committee on Prevention, Detection, Evaluation, and Treatment of High Blood Pressure; National High Blood Pressure Education Program Coordinating Committee. The seventh report of the Joint National Committee on Prevention, Detection, Evaluation, and Treatment of High Blood Pressure: the JNC 7 report. JAMA 2003;289:2560-72.

21. Expert Panel on Detection. Evaluation, and Treatment of High Blood Cholesterol in Adults. Executive Summary of the Third Report of the National Cholesterol Education Program (NCEP) Expert Panel on Detection. Evaluation, and Treatment of High Blood Cholesterol in Adults (Adult Treatment Panel III). JAMA 2001;285 2486-97.

22. McPherson R, Frohlich J, Fodor G, et al. Canadian Cardiovascular Society position statement - recommendations for the diagnosis and treatment of dyslipidemia and prevention of cardiovascular disease [published erratum in Can J Cardiol 2006;22: 1077]. Can J Cardiol 2006;22:913-27.

23. Grundy SM, Cleeman JI, Bairey Merz CN, et al.; Coordinating Committee of the National Cholesterol Education Program. Implications of recent clinical trials for the National Cholesterol Education Program Adult Treatment Panel III guidelines [published erratum in Circulation 2004;110:763]. Circulation 2004;110:227-39.

24. 2001 census. Ottawa (ON): Statistics Canada; modified 2003. Available: http://www12.statcan.gc.ca/english/census01/Products/ (accessed 2007 Apr. 13).

25. Canadian Community Health Survey (CCHS), cycles 1.1 (2000-2001), 2.1 (2003), 3.1 (2005). Ottawa (ON): Statistics Canada (accessed remotely 2008 Oct. 14).

26. National Population Health Survey (NPHS), cycles 1 (1994-1995), 2 (1996-1997). Ottawa (ON): Statistics Canada (accessed remotely 2008 Oct. 14).

27. Drug expenditure in Canada, 1985 to 2007. Ottawa (ON): Canadian Institute for Health Information; 2008

28. Dickson M, Jacobzone S. Pharmaceutical use and expenditure for cardiovascular disease and stroke: a study of 12 OECD countries. Paris (France): Organisation for Economic Co-operation and Development; 2003. DELSA/ELSA/WD/HEA(2003)1. Available: www.oecd.org/dataoecd/61/8/2502315.pdf (accessed 2009 Apr. 16).

29. Morgan S. Canadian prescription drug costs surpass $\$ 18$ billion. CMAJ 2005;172: 1323-4.

30. Rates and statistics: inflation calculator. Ottawa (ON): Bank of Canada; 2008. Available: www.bank-banque-canada.ca/en/rates/inflation_calc.html (accessed 2008 July 2)

31. CANSIM. Ottawa (ON): Statistics Canada; 2008. Available: http://cansim2.statcan .ca/cgiwin/cnsmcgi.exe?CANSIMFile=CII/CII_1_E.HTM\&RootDir=CII/\&LANG $=\mathrm{E}$ (accessed 2008 July 9). 
32. Morgan S. Drug spending in Canada — recent trends and causes. Med Care 2004; 42:635-42.

33. Patented Medicine Prices Review Board. PMPRB annual report 2005. Ottawa $(\mathrm{ON})$ : The Board; 2005. Available: www.pmprb-cepmb.gc.ca/English/View .asp? $\mathrm{x}=667 \& \mathrm{mp}=91$ (accessed 2009 Apr. 16).

34. Pilote L, Abrahamowicz M, Eisenberg M, et al. Effect of different angiotensinconverting-enzyme inhibitors on mortality among elderly patients with congestive heart failure. CMAJ 2008;178:1303-11.

35. Rinfret S, Behlouli H, Eisenberg MJ, et al. Class effects of statins in elderly patients with congestive heart failure: a population-based analysis. Am Heart J 2008; $155: 316-23$

36. Morgan SG, Bassett KL, Wright JM, et al. "Breakthrough" drugs and growth in expenditure on prescription drugs in Canada. BMJ 2005;331:815-6.

37. Patented Medicine Prices Review Board. Non-patented prescription drug prices reporting. Canadian and foreign price trends, June 2006. Ottawa (ON): The Board; 2006. Available: www.pmprb-cepmb.gc.ca/CMFiles/Canadian-Foreign _Price_Trends_-_released_July_04_0638LHG-742006-1490.pdf (accessed 2009 Apr. 16).

38. Federal/Provincial/Territorial Ministerial Task Force on the National Pharmaceuticals Strategy. National Pharmaceuticals Strategy: progress report. Ottawa (ON): Health Canada; 2006. Available: www.hc-sc.gc.ca/hcs-sss/pubs/pharma/2006-nps-snpp /index-eng.php (accessed 2008 July 2).

39. Campbell NRC, Tu K, Brant R, et al.; Canadian Hypertension Education Program Outcomes Research Task Force. The impact of the Canadian hypertension education program on antihypertensive prescribing trends Circulation 2006;47:22-8.

40. Tanuseputro P, Manuel DG, Leung M, et al. Risk factors for cardiovascular disease in Canada. Can J Cardiol 2003;19:1249-59.

Correspondence to: Dr. Cynthia Jackevicius, Western University of Health Sciences, College of Pharmacy, 309 E Second St., Pomona CA 91766, USA; fax 909 469-5539; cjackevicius@westernu.edu

\section{The Canadian Cardiovascular Outcomes Research Team:} Jack V. Tu, MD PhD, Institute for Clinical Evaluative Sciences, Sunnybrook Health Sciences Centre, University of Toronto; William Ghali MD MPH, University of Calgary; Louise Pilote MD $P h D$, Division of General Internal Medicine, McGill University and McGill University Health Centre; Jafna L. Cox BA MD, Division of Cardiology, Dalhousie University, Capital Health; Douglas S. Lee MD PhD, Institute for Clinical Evaluative Sciences, Division of Cardiology, Toronto General Hospital; Karin H. Humphries MBA DSc, Division of Cardiology, University of British Columbia; David Alter MD PhD, Institute for Clinical Evaluative Sciences, Division of Cardiology, St. Michael's
Hospital and the Toronto Rehabilitation Institute; Peter C. Austin PhD, Institute for Clinical Evaluative Sciences, Dalla Lana School of Public Health, University of Toronto; Mark J. Eisenberg MD MPH, Divisions of Cardiology and Clinical Epidemiology, Jewish General Hospital, McGill University; William M. Flanagan BM, Statistics Canada; P. Diane Galbraith BN MSc, Foothills Medical Centre, University of Calgary; Michelle M. Graham MD,

University of Alberta; Ansar Hassan MD PhD, Department of Cardiac Surgery, Saint John Regional Hospital, Atlantic Health Sciences Corporation; Gregory M. Hirsch MD, Department of Surgery, Dalhousie University; Thao Huynh MD MSc, Research Institute of the McGill University Health Centre; Cynthia A. Jackevicius PharmD MSc, Western University of Health Sciences, Institute for Clinical Evaluative Sciences; Helen L. Johansen PhD, Health Analysis Division, Statistics Canada, Department of Community Medicine and Epidemiology, University of Ottawa; Merril L. Knudtson MD, Libin Cardiovascular Institute of Alberta; Dennis T. Ko MD MSc, Division of Cardiology, Schulich Heart Centre, Sunnybrook Health Sciences Centre, University of Toronto, Institute for Clinical Evaluative Sciences; Michael P. Love MB ChB MD, Department of Medicine, Queen Elizabeth II Health Sciences Centre, Dalhousie University; Douglas G. Manuel MD MSc, Ottawa Health Research Institute; Colleen M. Norris, RN PhD (Epid), Faculties of Nursing and Medicine, University of Alberta; Wayne Putnam MD, Department of Family Medicine, Dalhousie University; Stéphane Rinfret MD MSc, Institut Universitaire de Cardiologie et de Pneumologie de Québec, Université Laval; Michael J. Schull MD MSc, Institute for Clinical Evaluative Sciences, Department of Medicine, University of Toronto; Derek Y. So MD, University of Ottawa Heart Institute; Therese A. Stukel PhD, Institute for Clinical Evaluative Sciences; Lawrence W. Svenson BGS DipPsych, Surveillance and Environmental Health, Alberta Health and Wellness, School of Public Health, University of Alberta; Christopher R. Thompson MD CM, St. Paul's Hospital, University of British Columbia; Karen Tu MD MSc, Institute for Clinical Evaluative Sciences, Department of Family and Community Medicine, University of Toronto; and Nancy A. Walton PhD, Daphne Cockwell School of Nursing Chair, Research Ethics Board, Ryerson University 